\title{
Study on Settlement and Deformation of Urban Viaduct Caused by Subway Station Construction under Complicated Conditions
}

\author{
Cong-shuang Luo $i$, Yi-hong Cheng, Zhe Bai, Tong Shen, Xu-Yang Wu, \\ and Qing-guo Wang
}

Henan University of Urban Construction, Pingdingshan 467036, China

Correspondence should be addressed to Cong-shuang Luo; 1cs128@163.com

Received 17 December 2020; Revised 6 February 2021; Accepted 20 February 2021; Published 28 February 2021

Academic Editor: Junhong Yuan

Copyright (c) 2021 Cong-shuang Luo et al. This is an open access article distributed under the Creative Commons Attribution License, which permits unrestricted use, distribution, and reproduction in any medium, provided the original work is properly cited.

\begin{abstract}
With the rapid development of urbanization, the speed of constructing urban underground space and ground foundation engineering is accelerated. With the shortage of land resources, the distance between underground engineering and surface engineering is getting closer and closer, and the contradictions and problems between projects are becoming more and more serious. Based on the new subway station, this paper passes the existing urban viaduct in a short distance. The settlement and deformation of pile foundation and buildings caused by the excavation of the subway station is studied by using ROCSCIENCE software and site monitoring method. The potential risk sources around the station are pile foundations $18.5 \mathrm{~m}$ away, residential buildings $15 \mathrm{~m}$ away, storm water pipes $7.3 \mathrm{~m}$ away, and high-pressure gas pipes at $5.6 \mathrm{~m}$. According to the construction requirements of pile foundation settlement deformation during metro station excavation, we set up construction standards. The settlement of the buildings and pipelines around the metro station should not exceed $3 \mathrm{~mm}$, and the horizontal displacement should not exceed $2 \mathrm{~mm}$. The diaphragm wall is adopted to surround the subway station, and the ground is reinforced by advanced grouting. The results show that, during the excavation of the foundation pit of the metro station, the ground and the building will have obvious settlement deformation and the depth of deformation can reach $9 \mathrm{~mm}$, which is more than the allowable value. The settlement deformation of the ground and the surrounding buildings can be controlled within $3 \mathrm{~mm}$ by strengthening the foundation pit support and ground advance-grouting reinforcement. The control of construction deformation can meet the construction requirements.
\end{abstract}

\section{Introduction}

The rapid progress of urbanization has increased the speed and intensity of urban infrastructure projects. The development concept of the three-dimensional city can effectively expand the three-dimensional space of the city. In the construction of ground infrastructure, the above ground space and the underground space can be explored. A large number of viaducts, ground roads, and subway projects lead to a fact that more and more urban infrastructure projects are getting closer and closer. The construction of small spacing projects has mutual influence and disturbance on the adjacent projects. The construction of the small-distance project has caused a certain number of engineering accidents and engineering disasters, which has seriously affected the urban environment and the life of urban residents. Many scholars have carried out a great deal of research work on urban safe construction and green construction [1-3]. A lot of scholars have carried out the related research work on subway safety construction [4-6]. As an underground linear project, the subway will intersect or underpass other projects in the construction process. The stability of rock strata and the safety of buildings in the intersecting area have become the focus and difficulty of research. More and more scholars will transfer the research center to the stability analysis of the building under the subway [7-9].

The stability analysis and emergency reinforcement treatment of the subway shield tunnel under existing structures are common. There are few studies on the underpass of urban-elevated roads by metro stations. Some scholars have carried out preliminary research and exploration on the subway station underpassing the existing engineering project. Yan et al. [10] studied the lifting technology of the subway passing under the bridge at short 
distance. Zhou et al. [11] analyzed the influence of the seismic effect of bridge pile foundation on the subway station. Peng et al. [12] used the time-history analysis method to study the ASEISMIC behavior of the subway station span bridge. Su et al. [13] studied the response of subway station construction to the bridge. Chen et al. [14] ran an emergency evacuation simulation of the bridge at the start of the connection. Kishii [15] carried out the use and management of the space under the railway viaduct and the underground space near the station. Wang et al. [16] carried out on-site monitoring and analysis of the construction process of the subway station. Li et al. [17] carried out numerical simulation and analysis of the shield tunnel under the pile foundation. Pan et al. [18] analyzed the effect of construction on the deformation of existing high-speed railway tunnels. Liu et al. [19] analyzed the mechanical properties and land subsidence characteristics of the supporting structure during the construction of the subway station. Lv et al. [20] studied the deformation of shield tunnels passing through piles of existing railway bridges. Zhao et al. [21] conducted a risk assessment for the construction of an elevated subway station. Yang and Wang [22] analyzed the effect of metro tunnel excavation on the deformation of existing stations. Jia et al. [23] studied the surface settlement and structural deformation of a new type of prebracing system for large-span subway stations. Zhang [24] carried out a study of shield tunneling through viaduct pile foundation underpinning.

The subway is built on a large scale in the city, and the situation of intersection with the urban-elevated road is more and more protruding. The metro shield tunnel often underpasses the existing urban viaduct, which has a serious safety impact on the pile foundation. Researchers studied the effects of subway tunnels on nearby pile foundation [25-27]. While, the metro shield tunnel underpasses the viaduct, some metro stations are also built under the urban viaduct, which makes the construction of metro stations have a serious safety impact on the adjacent pile foundations. Some scholars have analyzed and studied the influence of deep foundation pit excavation on adjacent bridge piles [28-30]. There are few cases of the subway station crossing the urban viaduct, and the research on this aspect is still rare. In this paper, a metro station under the city viaduct is used as the research object, through numerical simulation and field monitoring analysis of the subway station construction on the adjacent pile foundation stability. The deformation law and characteristics of the ground surface and adjacent buildings during the construction of the subway station are obtained. The research results are of great practical significance to the construction of the subway station under the urban viaduct. This study is of great significance to the design and construction of similar projects.

\section{Project Profile and Environmental Conditions}

2.1. Engineering Overview. The new metro station is located under the urban viaduct, and the station foundation pit is located between the two piles of viaduct. The minimum distance between the station foundation pit and the pile foundation is $18.5 \mathrm{~m}$. The subway station is a two-storey underground island station, which is constructed by opencut construction.

The main structure is a double-column three-span reinforced concrete box-frame structure. The total length of the station is $180 \mathrm{~m}$; the width of the standard section is $19.7 \mathrm{~m}$; the depth of the floor of the standard section is about $19.8 \mathrm{~m}$, and the soil cover of the roof is $3.5 \mathrm{~m}$.

The station has 4 entrances and 2 wind pavilions. The viaduct near the metro station adopts pile foundation with double-row piles. The length of the pile is $39.3 \mathrm{~m}$, and the diameter is $0.8 \mathrm{~m}$. Four piles are set under each pile cap. The location of the subway station and the pile foundation is shown in Figures 1 and 2.

2.2. Engineering Geological Conditions. There are miscellaneous fill, clay, silty soil, silty sand, and sandstone in the area where the subway station is located. The main structure of the subway station is in silty soil and silty clay. The engineering geological section is shown in Figure 3.

2.3. Built Environment. There are viaduct pile foundations, multistorey residential buildings, and municipal pipelines near the new metro station. The buried objects in the main structure of the subway station are mainly municipal pipelines. The main pipelines are rainwater pipe DN1000, buried depth of 1.4 meters, and 7.3 meters from the subway station; high-pressure gas pipe DN300, buried depth of 1.5 meters, and 5.6 meters from the subway station; sewage pipe DN1200, buried depth of 5.5 meters, and 10.5 meters from the subway station. The built environment around the station is shown in Figure 4. The section of the pipe is shown in Figure 5.

2.4. Engineering Monitoring. According to the evaluation report and design requirements of the newly built subway station under the existing urban-elevated road area, the vertical settlement value of the pile foundation and the urban viaduct should not exceed $3 \mathrm{~mm}$, and the horizontal displacement should not exceed $2 \mathrm{~mm}$. In order to ensure that the construction does not have a significant impact on the existing urban viaduct, it is necessary to monitor the stratum, underground diaphragm wall, pile foundation, pipeline, etc. The monitoring arrangement is shown in Figure 6.

The deformation control level of the station foundation pit is the first level, and the soil from the side of the pit to the building should be reinforced by grouting before the excavation. The retaining structure and internal support system of the foundation pit should be strengthened, and the support measures should be added when necessary to strictly control the deformation of adjacent pile foundation. The monitoring frequency of adjacent pile foundation and building is encrypted during the construction of the foundation pit, and the construction parameters are adjusted according to the monitoring results to ensure the safety of the building. 


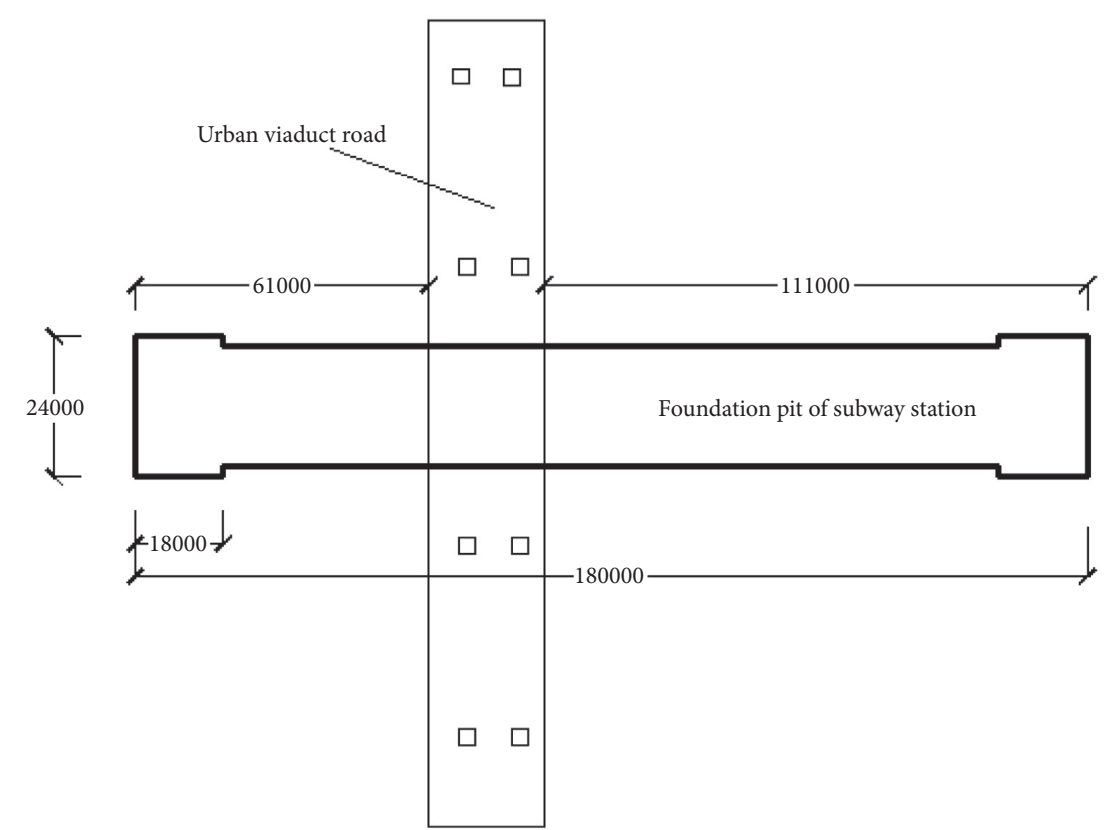

FIgURE 1: Relationship between the viaduct and subway station plane position.

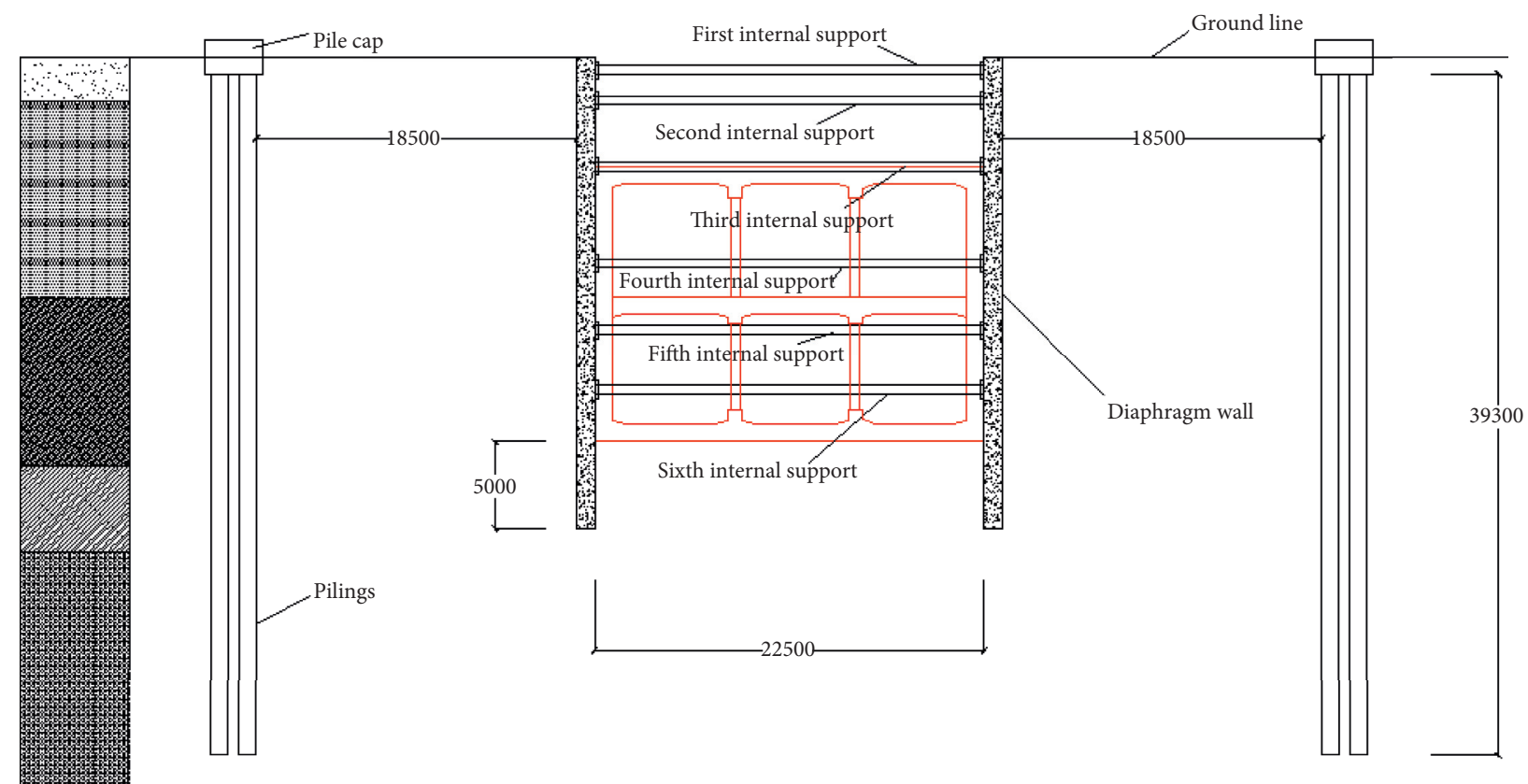

FIGURE 2: The section position relation between subway station and pile foundation.

2.5. Reinforcement Measures. According to the construction safety requirement, the soil layer between the foundation pit and the pile foundation of the subway station needs to be reinforced by grouting. Four jet-grouting piles are arranged around the pile to reinforce it. The diameter and length of the jet-grouting pile are $800 \mathrm{~mm}$ and $2000 \mathrm{~mm}$, respectively. The high-pressure jet-grouting piles are made of common Portland cement with a strength of 42.5 grade. The water cement ratio of cement slurry is $0.8 \sim 1.2$. We reinforced the ground around the foundation pit of the subway station by grouting. The ground grouting measures is shown in Figure 7.

\section{Numerical Modeling}

3.1. Model Building. Combining with the actual situation of this project, ROCSCIENCE analysis software is selected to establish the numerical model. According to the 


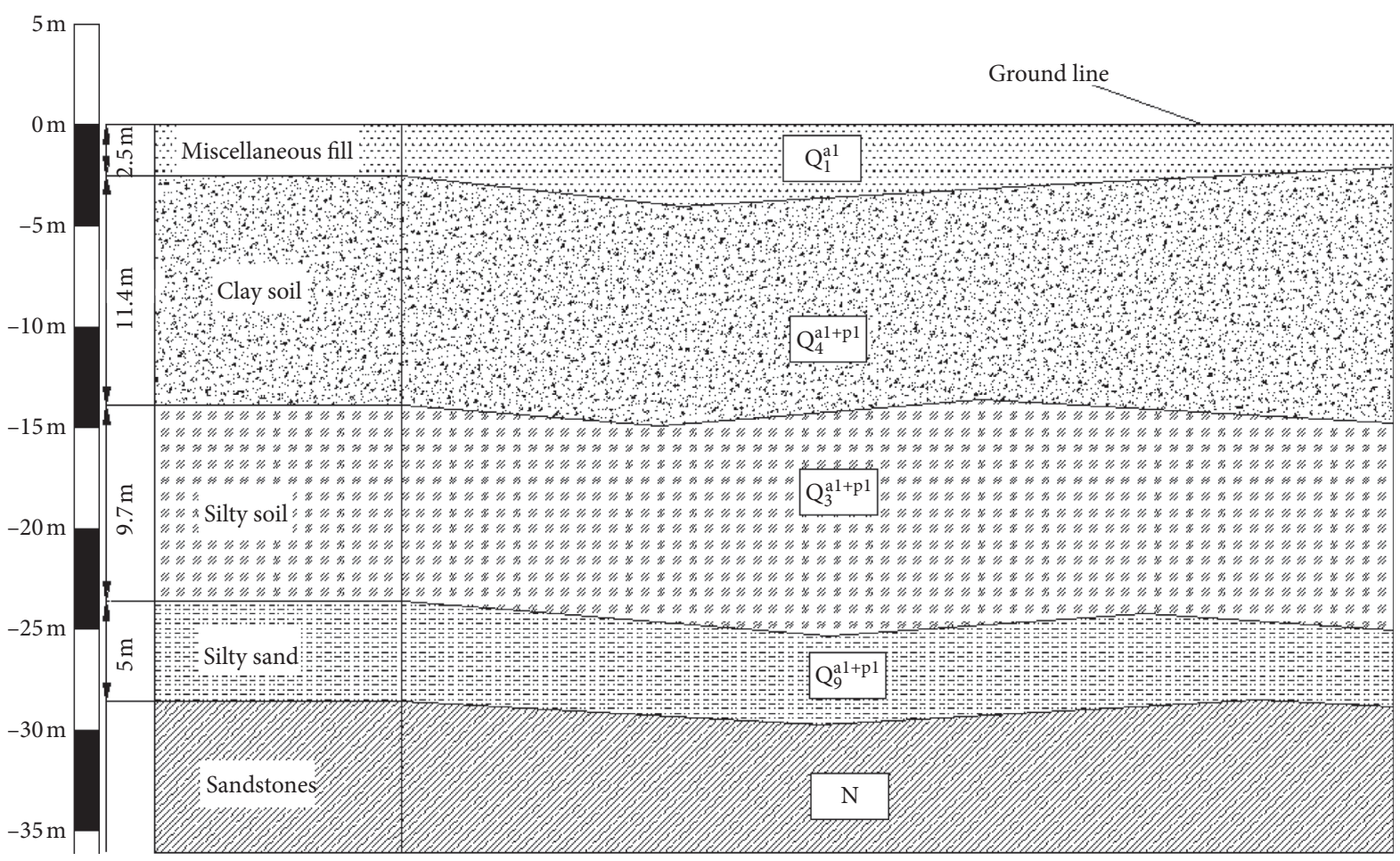

FIGURE 3: Section map of engineering geology.

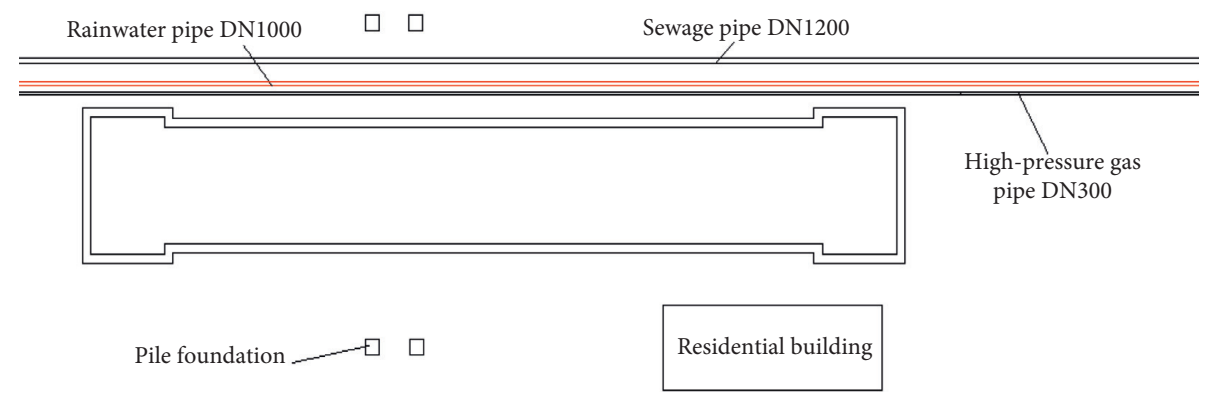

FIgURE 4: The layout of a subway station.

construction size requirement of the subway station, the size of this model is 300 meters long, 180 meters wide, and 60 meters thick, as shown in Figures 8 and 9.

\subsection{Parameter Selection. A modified Mohr-Coulomb} model based on the actual engineering characteristics is adopted. The linear elastic constitutive relation is applied to the structural element. The model combines nonlinearity with plasticity. The concrete elements of pile foundation and soil in the model are solid elements. The rigid-flexible contact element is used to simulate the nonlinear behavior of the pile-soil interface. The nonlinearity between pile and soil is simplified to a thinwalled element. The beam element is used to simulate the internal supporting structure, crown beam, and column pile. The parameters required for the numerical simulation are shown in Table 1.
3.3. Construction Procedures. The excavation depth of the foundation pit of the metro station is $19.8 \mathrm{~m}$, and the retaining structure is an underground diaphragm wall, and the embedded depth of the diaphragm wall is $10 \mathrm{~m}$. The foundation pit was excavated 6 times, and 6 transverse supports were set up. According to the engineering practice, the construction stage is divided into 6 working conditions, as shown in Figure 10.

\section{Numerical Simulation and Analysis}

4.1. Numerical Analysis of Influence of Metro Station Excavation on Surrounding Environment Deformation. The construction process of the subway station is numerically simulated by simulation software. The settlement and deformation of surrounding strata, pile foundation, and other structures are studied. The simulation results are shown in Figure 11. 

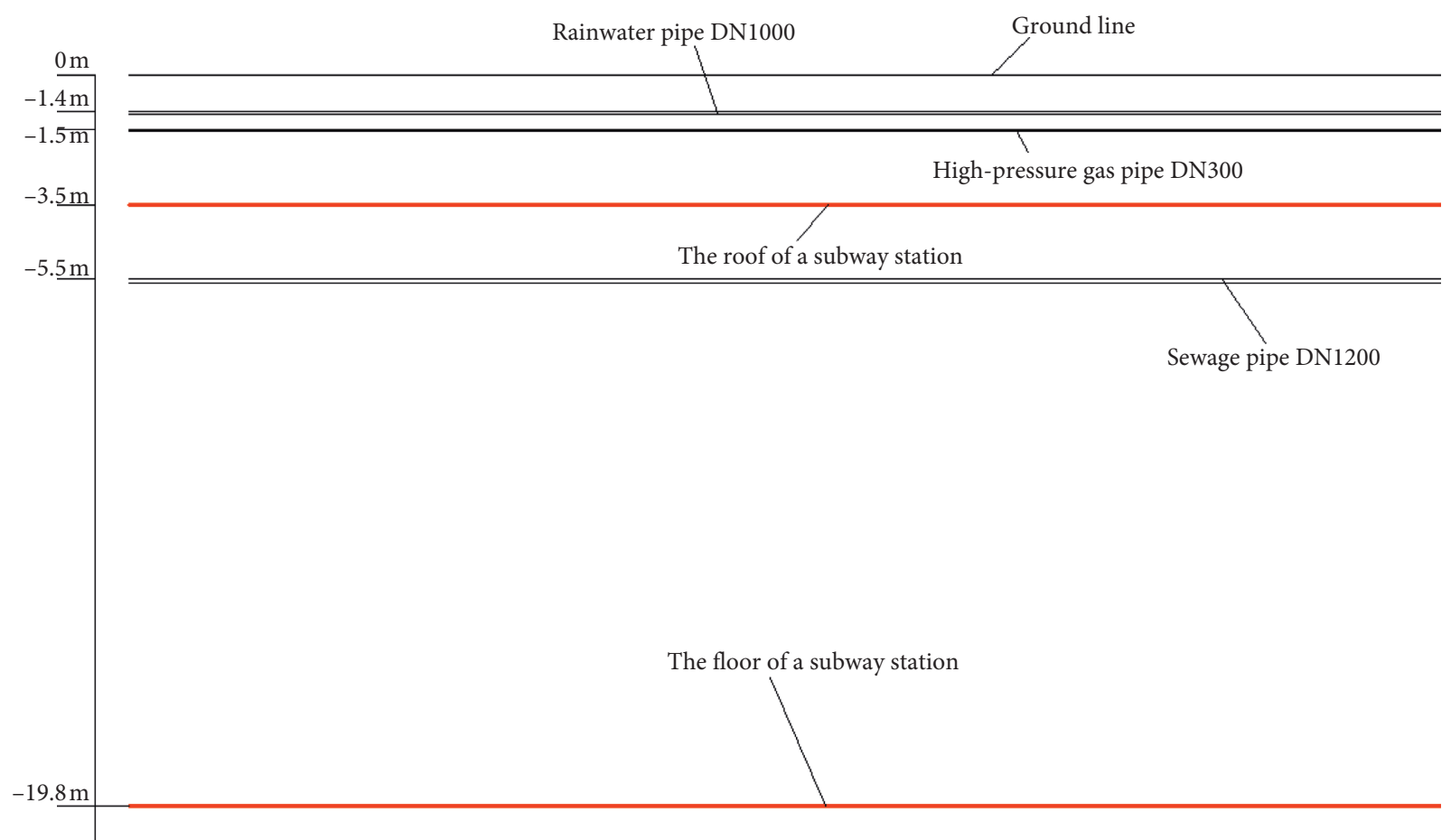

FIGURE 5: Sectional view of a subway station.

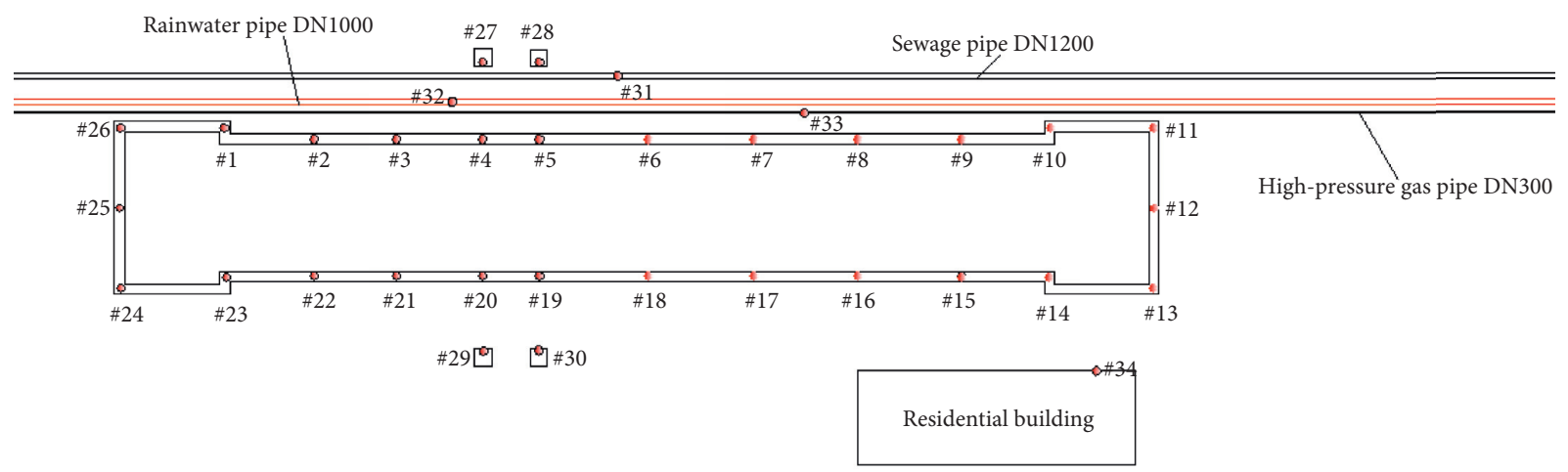

FIgURE 6: Monitoring the site layout.

As is shown in Figure 11, the foundation pit of the new subway station has a remarkable influence on the surrounding strata and deep foundation during the construction process. The maximum settlement is $9 \mathrm{~mm}$, which exceeds the limit of the engineering safety requirement. The excavation of the subway station in soft soil will inevitably lead to the deformation of surrounding strata and buildings.

4.2. Analysis of the Influence of the Distance between Pile Foundation and Foundation Pit. The excavation of the foundation pit of the metro station will cause deformation and destruction of surrounding strata. The ground settlement between the foundation pit and pile foundation during construction is shown in Figure 12.

As is shown in Figure 12, the soil layer between the pile foundation and the foundation pit has obvious settlement deformation during the excavation of the foundation pit of the subway station. Because this area is made of soft soil stratum, under the condition of excavation disturbance, thixotropy will occur in the soil layer and lead to settlement deformation. The influence range of settlement is about 


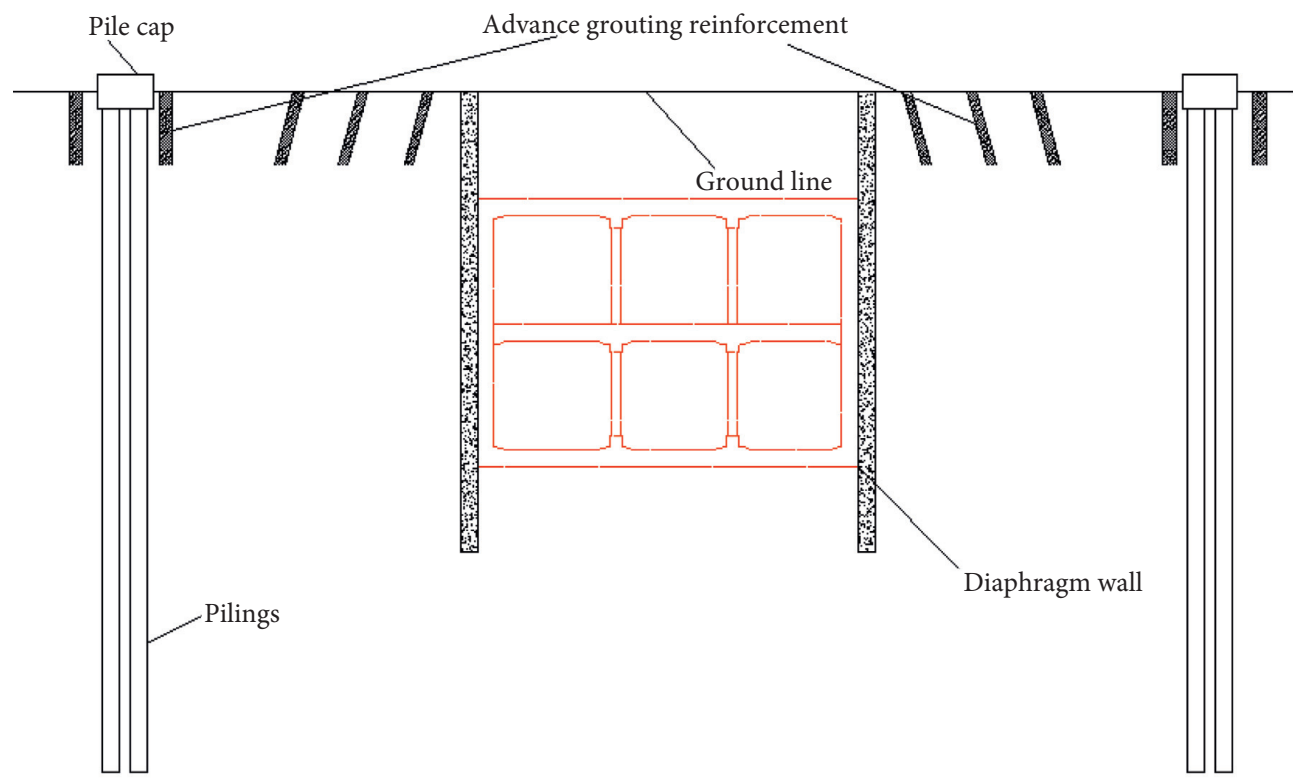

Figure 7: Ground grouting measures.

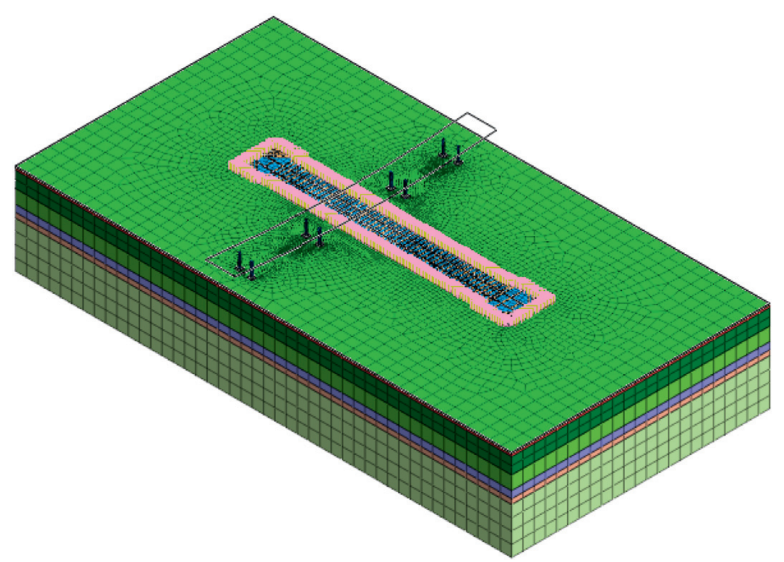

FIgURE 8: Three-dimensional geometric model.

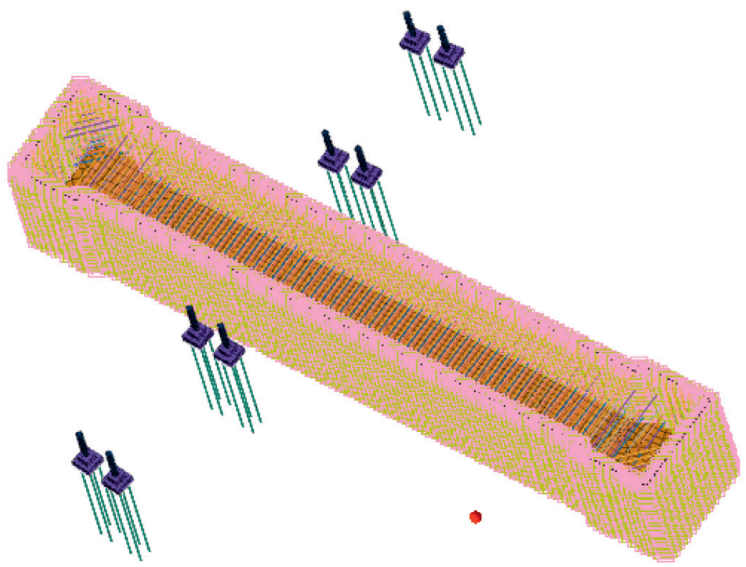

Figure 9: Model map of the foundation pit of the metro station. 
TABle 1: Physical and mechanical properties of the wall rock.

\begin{tabular}{lccccccc}
\hline Layer number & Name of soil layer & $h(\mathrm{~m})$ & $\Gamma\left(\mathrm{kN} / \mathrm{m}^{3}\right)$ & $\varphi\left({ }^{\circ}\right)$ & $c\left(\mathrm{kN} / \mathrm{m}^{2}\right)$ & $v$ & Elastic modulus $\left(\mathrm{kN} / \mathrm{m}^{2}\right)$ \\
\hline 1 & Miscellaneous fill & 2.5 & 1.75 & 6 & 8 & 0.37 & $9 e 3$ \\
2 & Clay soil & 11.4 & 20.3 & 12 & 48 & 0.33 & $1.61 \mathrm{e} 4$ \\
3 & Silty soil & 9.7 & 20.3 & 23 & 30 & 0.3 & $3.0 \mathrm{e} 4$ \\
4 & Silty sand & 5 & 21 & 25 & 0 & 0.35 & $1.63 e 4$ \\
5 & Sandstones & 3.6 & 21.8 & 30 & 35 & 0.35 & $1.5 e 5$ \\
6 & Pile foundation & - & 25 & 36 & 30 & 0.2 & $3.15 e 7$ \\
7 & Diaphragm wall & - & 22 & 36 & 30 & 0.2 & $2 e 7$ \\
\hline
\end{tabular}

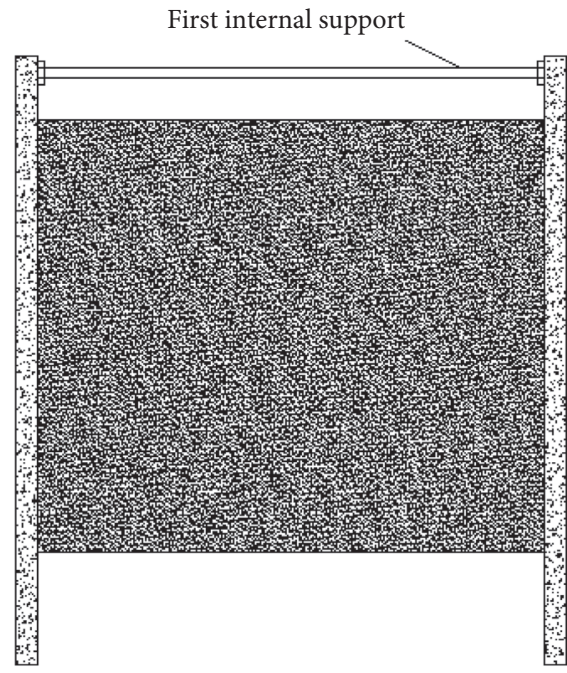

(a)

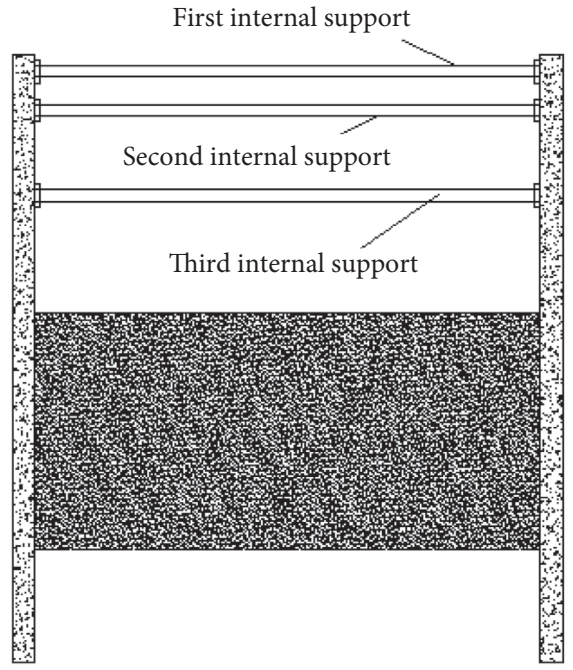

(c)

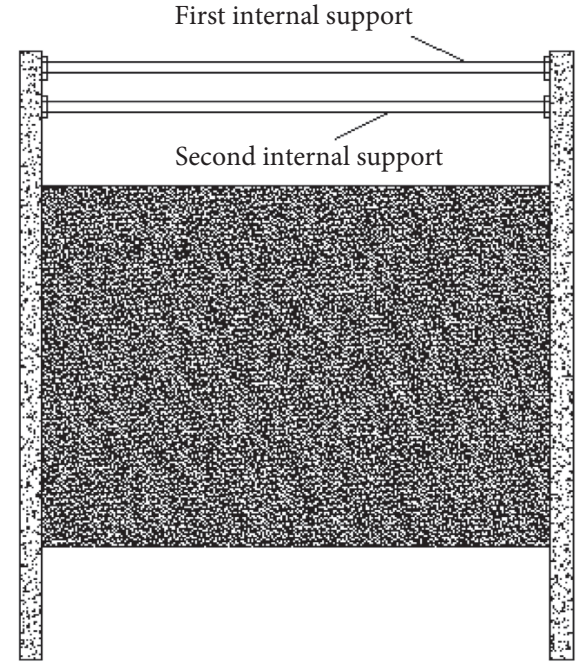

(b)

First internal support

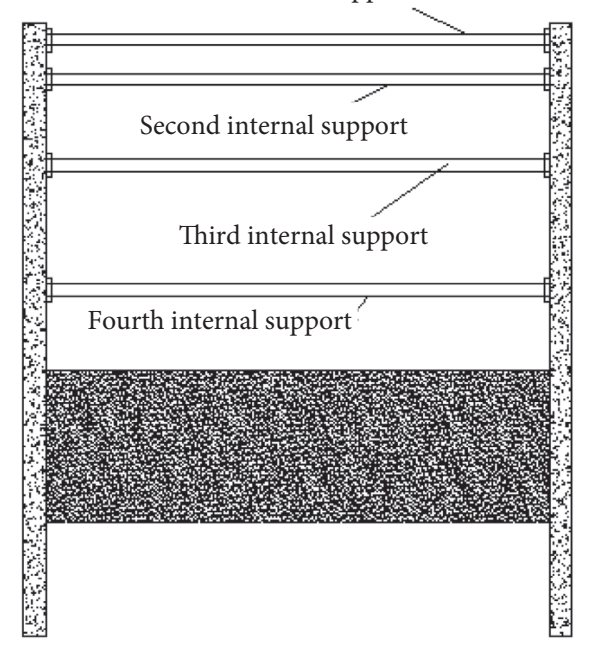

(d)

FIgURe 10: Continued. 


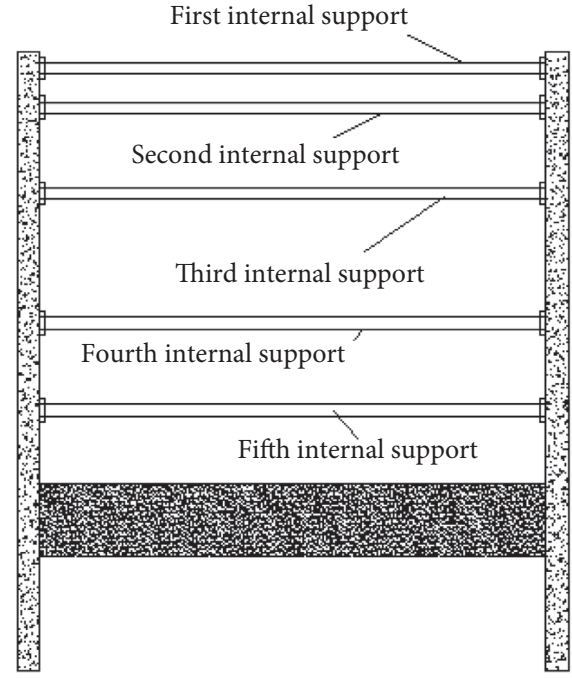

(e)

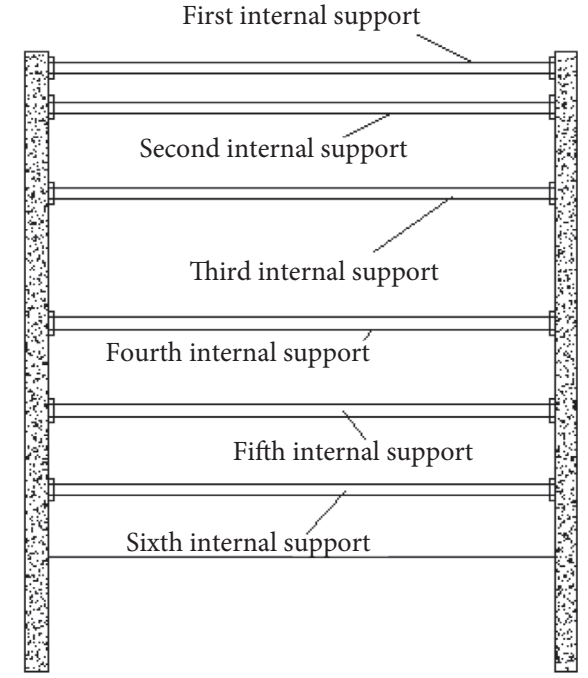

(f)

FIGURE 10: Construction condition. (a) Working condition 1. (b) Working condition 2. (c) Working condition 3. (d) Working condition 4. (e) Working condition 5. (f) Working condition 6.

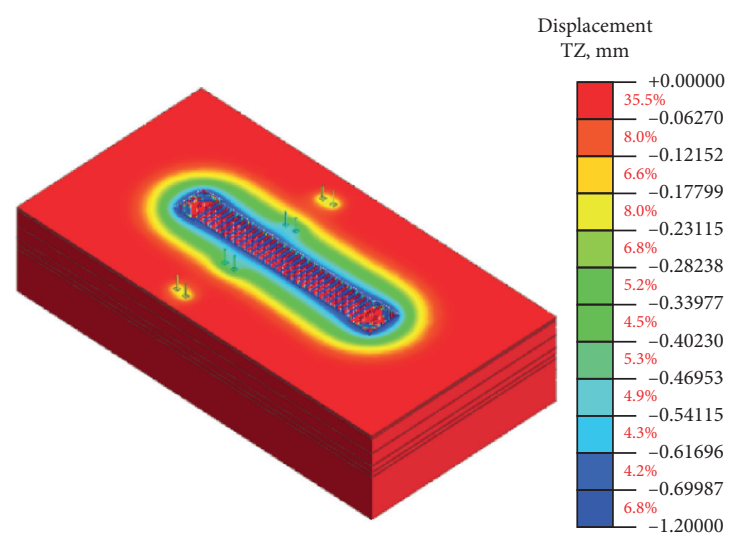

(a)

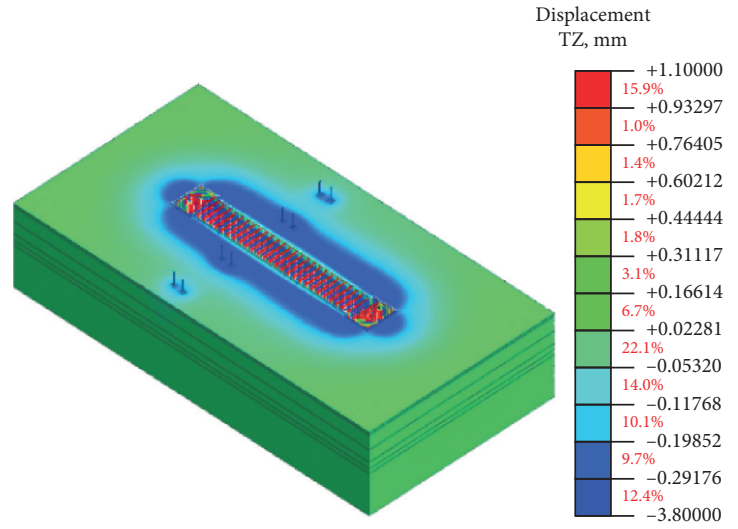

(c)

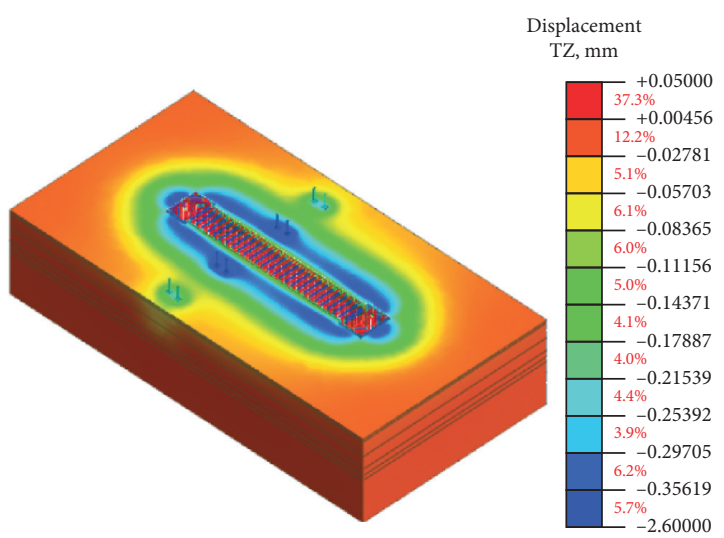

(b)

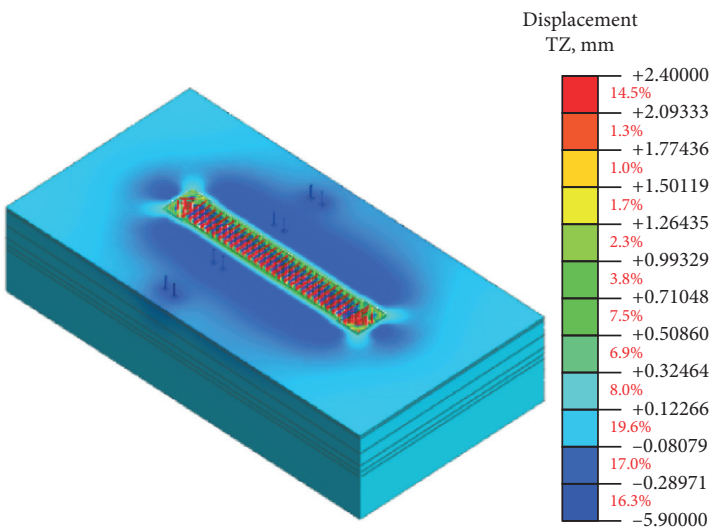

(d)

Figure 11: Continued. 


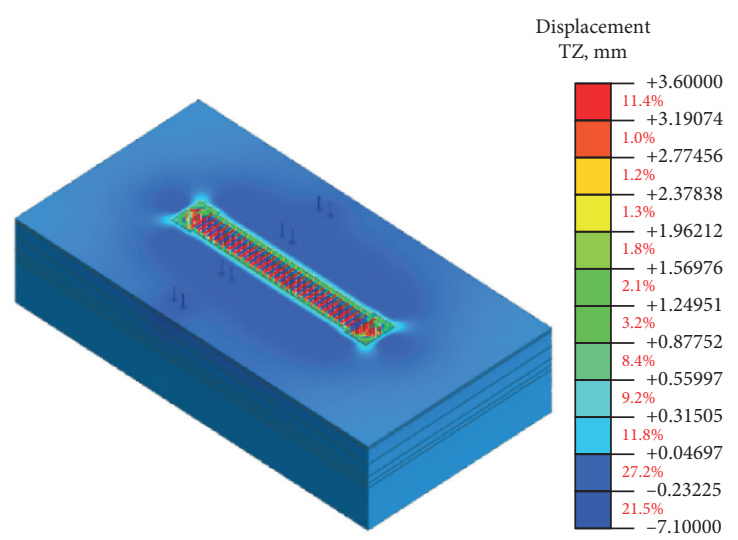

(e)

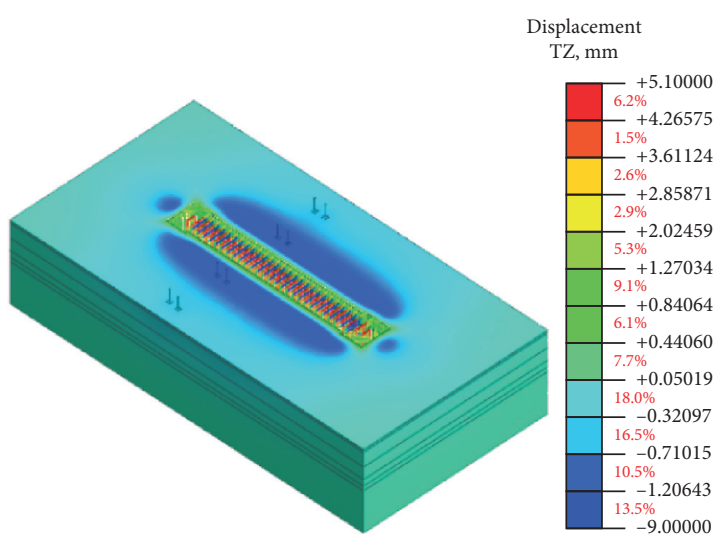

(f)

FIgURE 11: Settlement deformation nephogram. (a) Working condition 1. (b) Working condition 2. (c) Working condition 3. (d) Working condition 4. (e) Working condition 5. (f) Working condition 6.

$20 \mathrm{~m}$, the maximum settlement is $6 \mathrm{~m}$ from the foundation pit, and the settlement is close to $7 \mathrm{~mm}$.

The ground deformation after grouting the stratum is shown in Figure 13.

As is shown in Figure 13, the ground deformation is effectively controlled by grouting reinforcement. The maximum deformation is $2.52 \mathrm{~mm}$, which meets the construction standard.

\subsection{Deformation Analysis of the Diaphragm Wall during} Excavation. In the process of excavation of the subway station foundation pit, the diaphragm wall also has some deformation. The horizontal displacements of survey points 4 and 20 on the diaphragm wall are shown in Figure 14.

As is shown in Figure 14, during the excavation of the foundation pit, significant horizontal displacement of the diaphragm wall occurred, which was close to $8 \mathrm{~mm}$, exceeding the construction safety limit. In order to ensure that the construction of the surrounding buildings meets the construction requirements, it is necessary to increase the strength of the foundation pit and ground reinforcement.

The deformation of the diaphragm wall after reinforcement by grouting is shown in Figure 15 .

As is shown in Figure 15, the deformation of the stratum and diaphragm wall is effectively controlled after grouting reinforcement. The maximum vertical settlement and the maximum horizontal displacement of the diaphragm wall are $2.45 \mathrm{~mm}$ and $1.42 \mathrm{~mm}$, respectively, which meet the construction requirements.

4.4. Analysis of Deformation in Pile Foundation. The deformation of the pile foundation of the viaduct is caused by the excavation of the foundation pit of the metro station. The displacement and deformation of pile foundation are shown in Figure 16.

As is shown in Figure 16, the pile foundation adjacent to the subway station produces significant deformation during the excavation of the subway station. The vertical settlement of pile foundation is $6.25 \mathrm{~mm}$, and the horizontal deformation is $3.54 \mathrm{~mm}$. The main causes of pile foundation deformation are as follows: first, the load of the urban-elevated road is larger, second, the surrounding area is soft soil, and third, the subway construction distance is closer.

The deformation of the pile foundation after grouting the ground around pile foundation is shown in Figure 17.

As is shown in Figure 17, the settlement of pile foundation is effectively controlled and restrained after grouting reinforcement. The maximum vertical settlement of pile foundation is $1.63 \mathrm{~mm}$, and the maximum horizontal displacement is $1.53 \mathrm{~mm}$.

\section{On-Site Monitoring and Reinforcement Effect}

5.1. Deformation and Analysis of Land Subsidence. During the construction of the foundation pit in the metro station, the ground settlement data are obtained by monitoring the ground settlement between the diaphragm wall and pile foundation. The surface settlement deformation curve is shown in Figure 18.

As is shown in Figure 18, the subsidence deformation of the ground surface has been effectively controlled by grouting. The maximum position of ground settlement deformation is about $7 \mathrm{~m}$ from the foundation pit. The maximum surface settlement is $2.47 \mathrm{~mm}$, which does not exceed the allowable value and meets the construction requirements.

5.2. Deformation and Analysis of the Enclosure Structure. According to the requirement of construction safety, the deformation of the diaphragm wall is monitored. The horizontal displacement and vertical settlement of the diaphragm wall are shown in Figures 19 and 20.

As is shown in Figures 19 and 20, the deformation of the diaphragm wall during the whole construction process is 


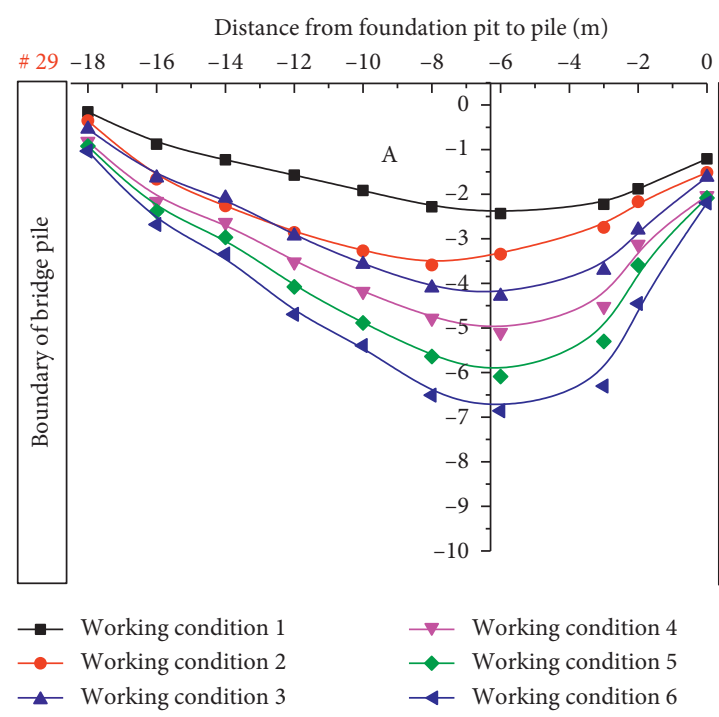

(a)

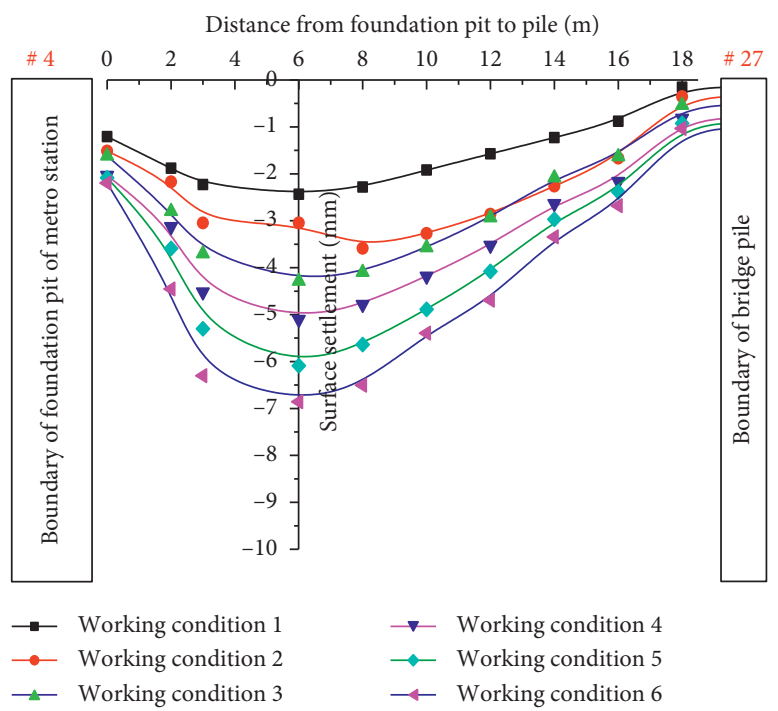

(b)

FIGURE 12: Surface settlement curves under different working conditions. (a) Line 29-20. (b) Line 4-27.

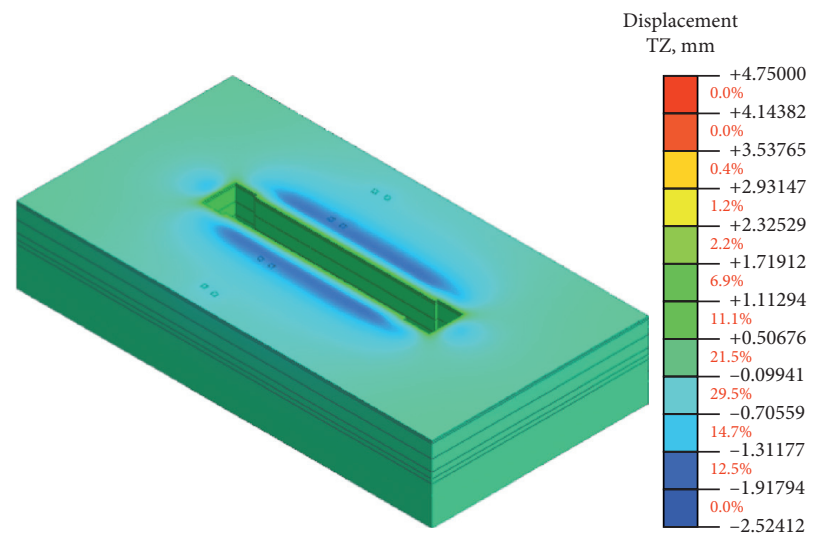

FIGURE 13: Cloud map of ground settlement after grouting reinforcement.

not large and does not exceed the allowable value. Grouting reinforcement has effectively controlled the deformation and failure of the diaphragm wall. The maximum horizontal displacement is $1.51 \mathrm{~mm}$, and the maximum vertical settlement is $2.51 \mathrm{~mm}$, which meets the construction standard.

5.3. Deformation and Analysis of Pile Foundation. The key and difficult point of this construction is the influence of the subway station on the urban viaduct. In order to ensure that the pile foundation does not deform and does not affect the normal operation of the existing road, grouting reinforcement is adopted. During the construction, we monitored the pile foundation. The deformation data of pile foundation are shown in Figures 21 and 22 .

As is shown in Figures 21 and 22, the deformation and failure of pile foundation are effectively controlled by grouting. The maximum horizontal displacement of pile foundation is $1.69 \mathrm{~mm}$, and the maximum vertical settlement is $1.70 \mathrm{~mm}$, which meets the construction standard.

5.4. Deformation and Analysis of Pile Foundation. The key and difficulty of foundation pit construction in the metro station is that there are all kinds of pipelines and multistorey residential buildings near the foundation pit. In order to prevent the subway station construction to the pipeline and the building influence, we have carried on the safety monitoring during the construction. The accumulative vertical settlement of important monitoring points in the construction of the metro foundation pit is shown in Table 2.

As is shown in Table 2, the maximum settlement of the sewage pipe is $0.7 \mathrm{~mm}$, the maximum settlement of the rainwater pipe is $0.4 \mathrm{~mm}$, the maximum settlement of the high-pressure gas pipe is $0.7 \mathrm{~mm}$, and the maximum settlement of the residential building is $1 \mathrm{~mm}$, which meets the requirements and standards of safe construction. 


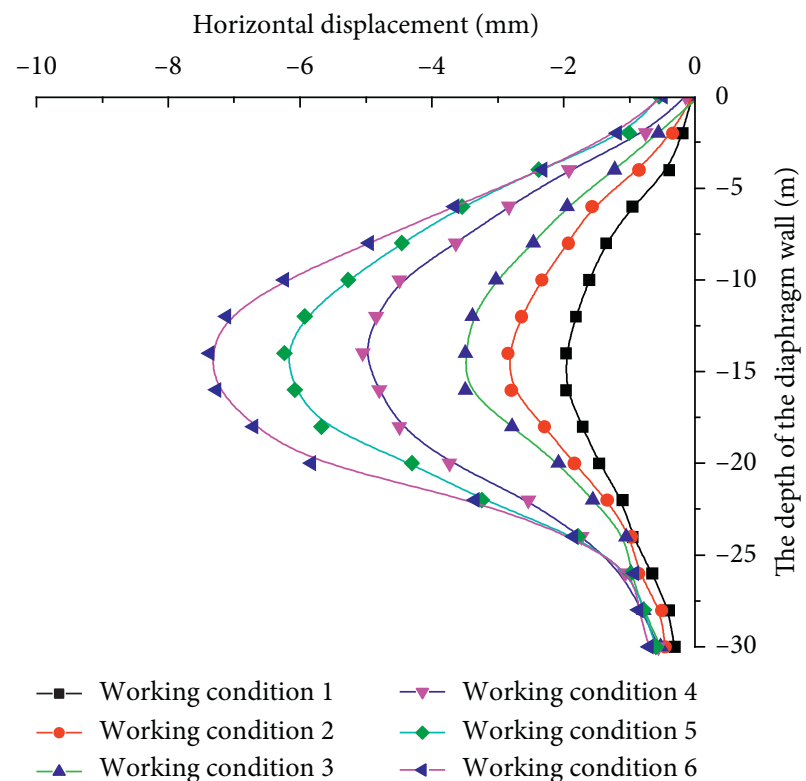

(a)

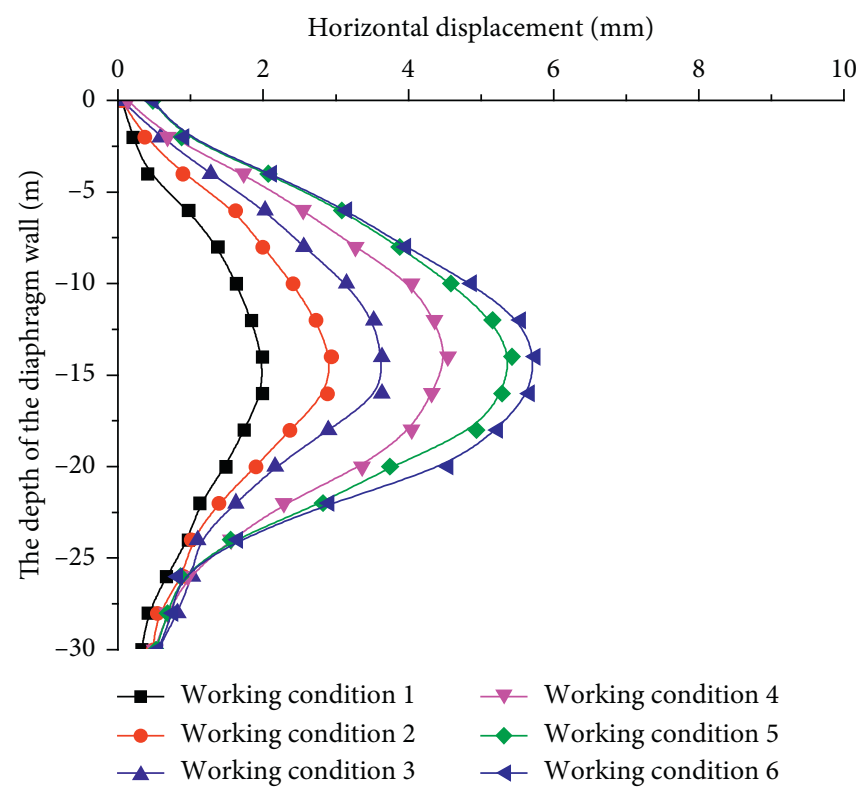

(b)

Figure 14: Horizontal displacement curves at different monitoring points. (a) Measuring point 20. (b) Measuring point 4.

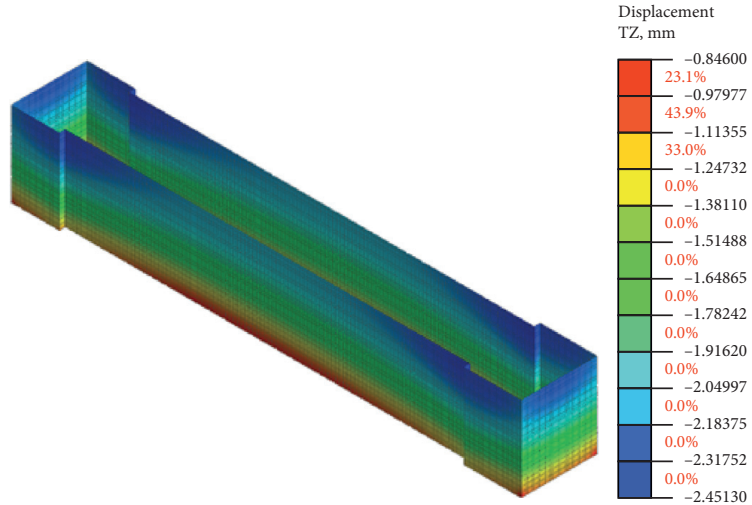

(a)

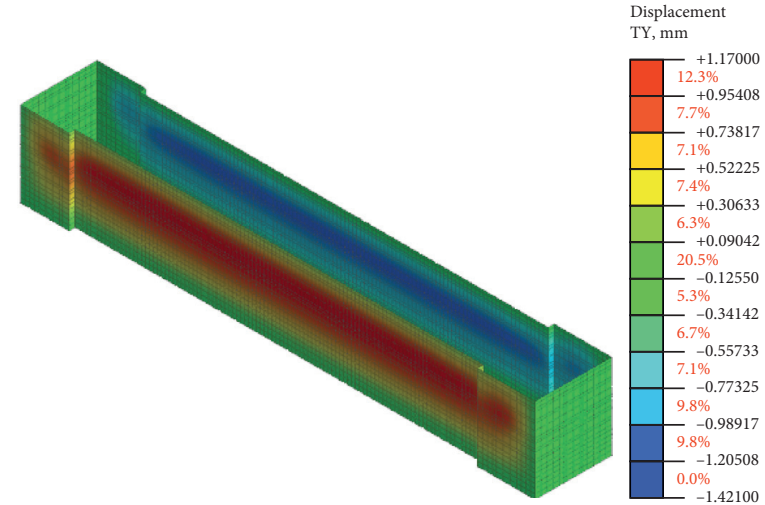

(b)

FIGURE 15: Displacement diagram of the diaphragm wall after grouting reinforcement. (a) Settlement diagram. (b) Horizontal displacement diagram.

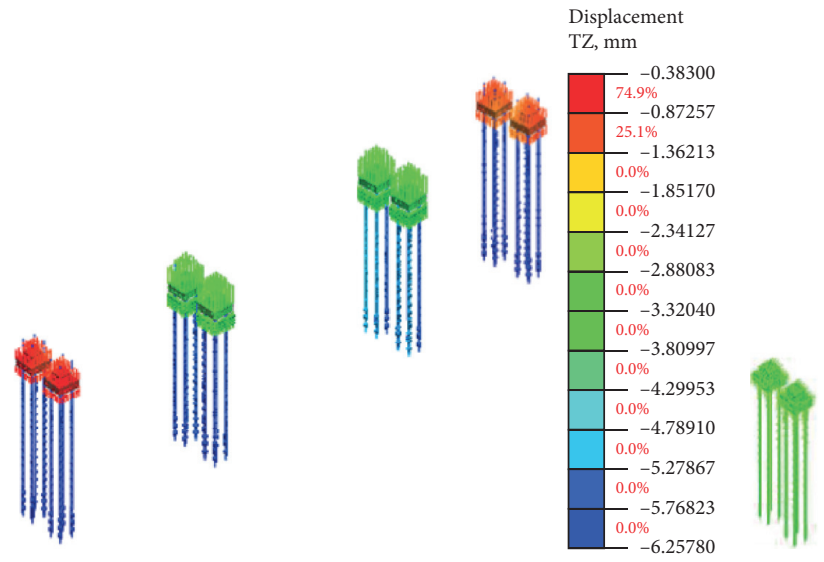

(a)

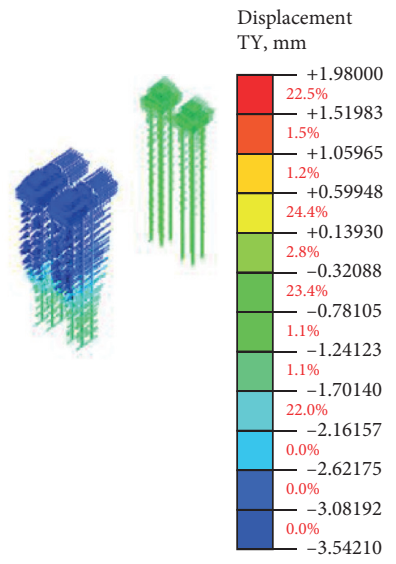

(b)

FIGURE 16: Morphing clouds of pile foundation. (a) Settlement diagram. (b) Horizontal displacement diagram. 

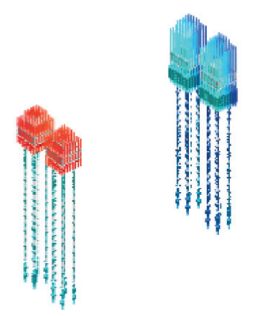

(a)

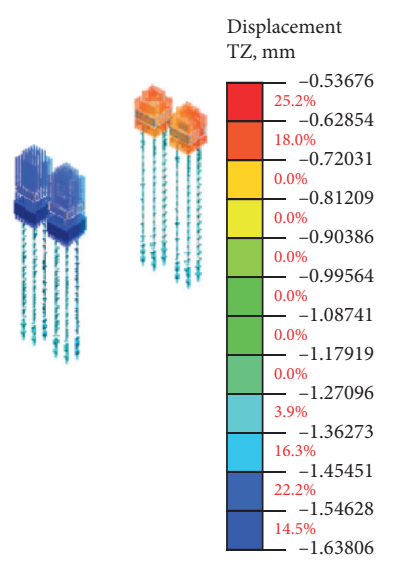

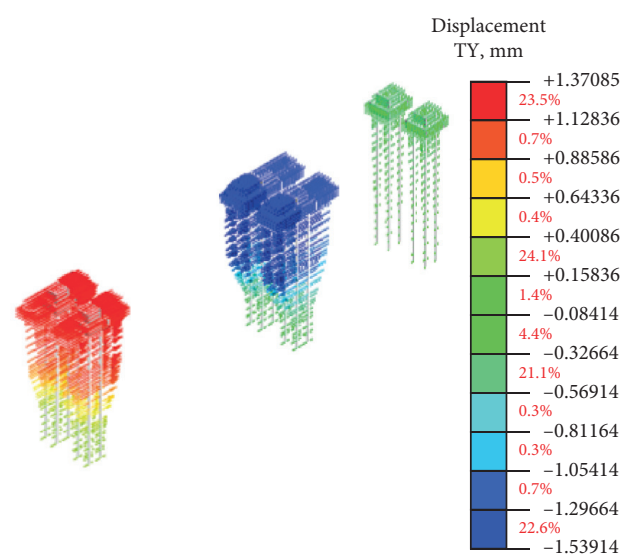

(b)

Figure 17: Displacement diagram of pile foundation after grouting reinforcement. (a) Settlement diagram. (b) Horizontal displacement diagram.

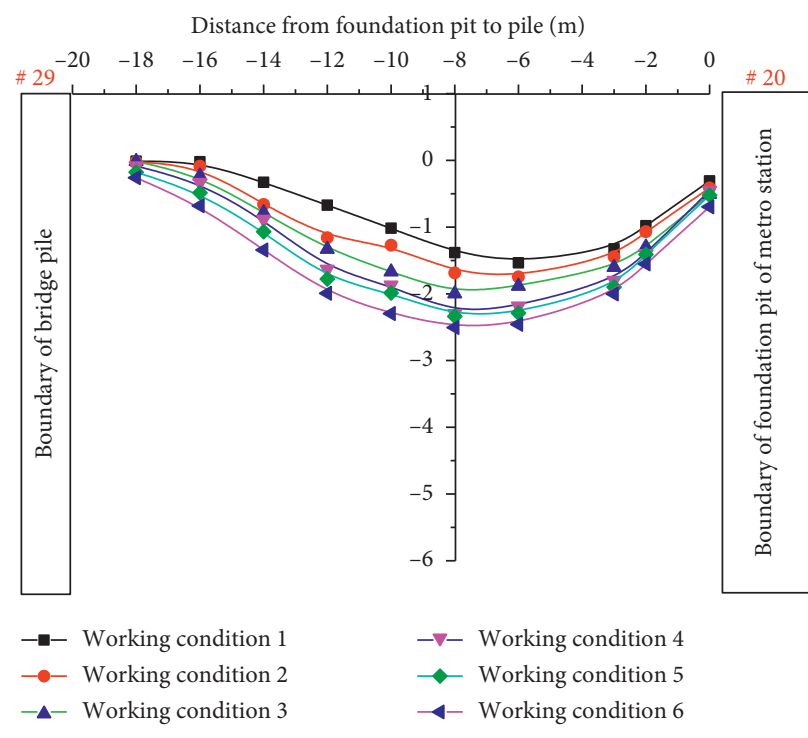

(a)

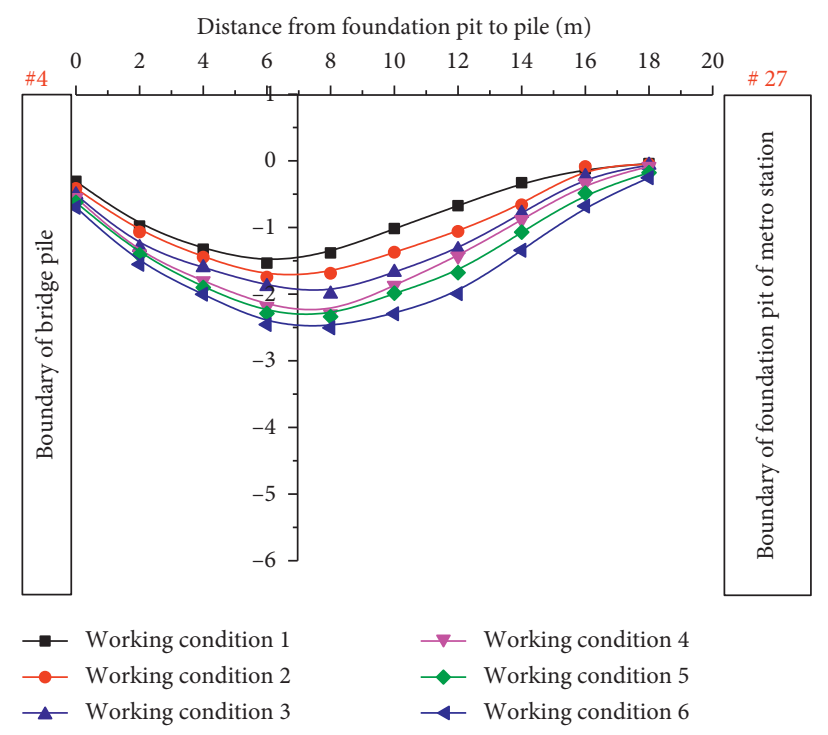

(b)

FIGURE 18: Surface settlement curves under different working conditions. (a) Line 29-20. (b) Line 4-27.

\section{Comparison of Numerical Simulation and Monitoring Results}

In this paper, the influence of foundation pit construction of the metro station on adjacent buildings is studied by numerical simulation and on-site monitoring. Comparisons between numerical simulations and field monitoring are shown in Table 3.

The results of numerical simulation and field monitoring are basically consistent with the maximum error of $5.9 \%$. The results of numerical simulation can provide reference for field construction. 


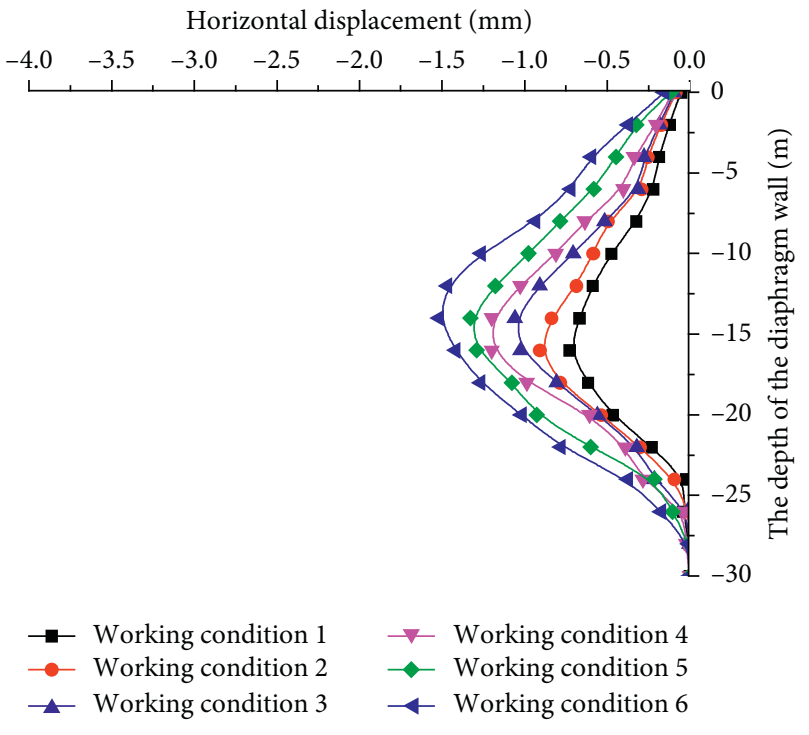

(a)

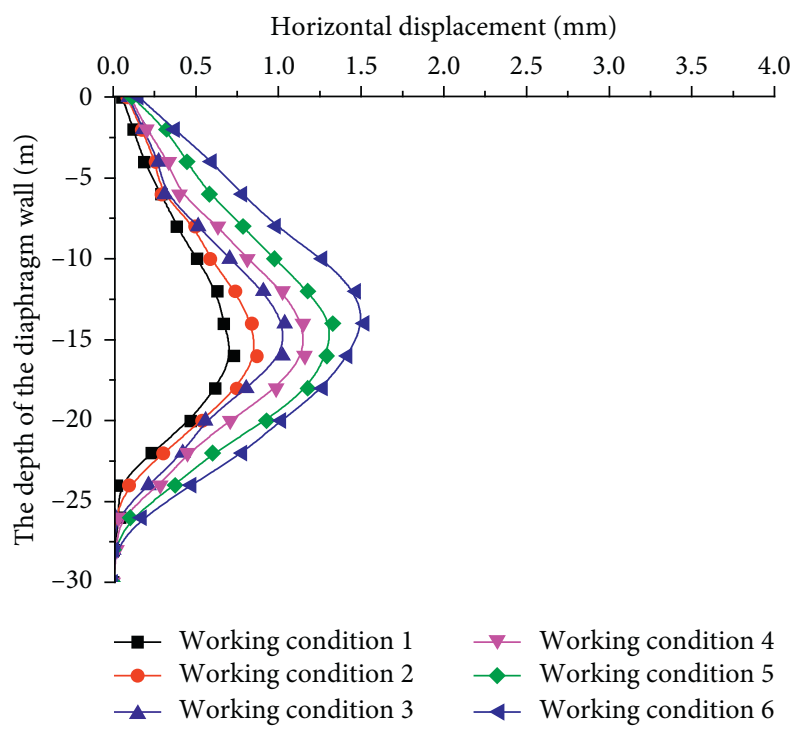

(b)

FIGURE 19: Horizontal displacement of the diaphragm wall under different working conditions. (a) Measuring point 20. (b) Measuring point 4.

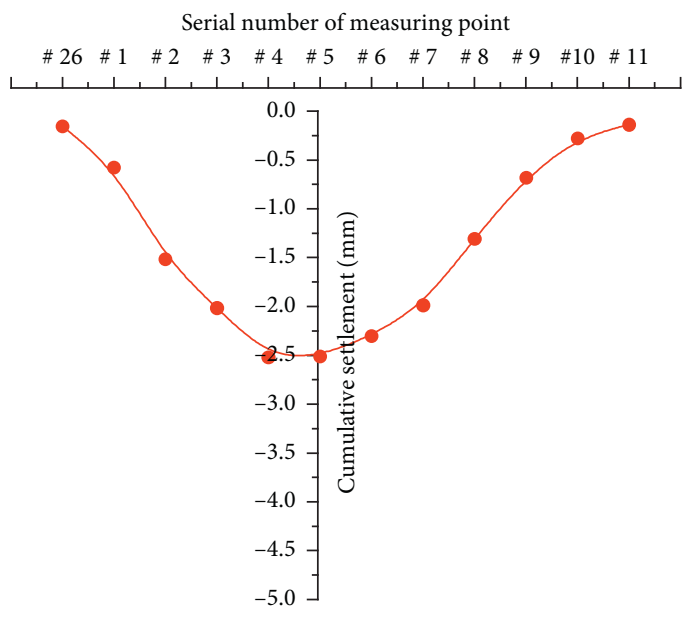

(a)

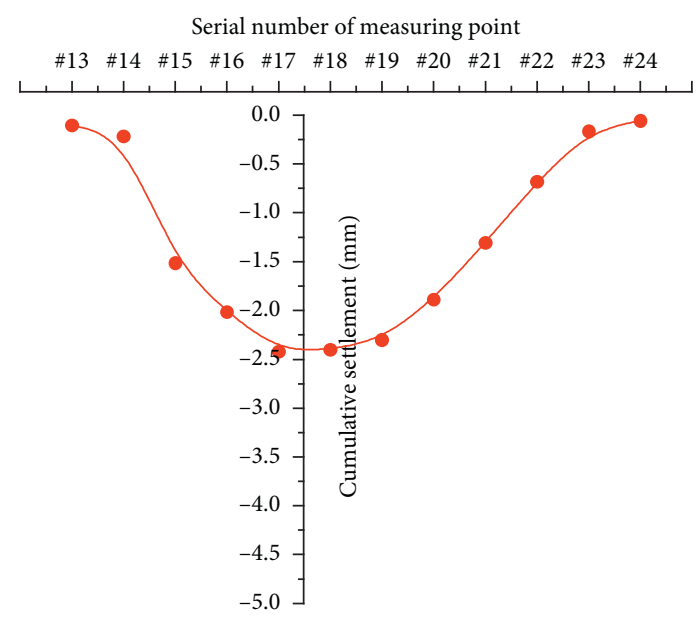

(b)

FIGURE 20: Settlement curve of the diaphragm wall at each measuring point. (a) Measuring point 26-11. (b) Measuring point 13-24. 


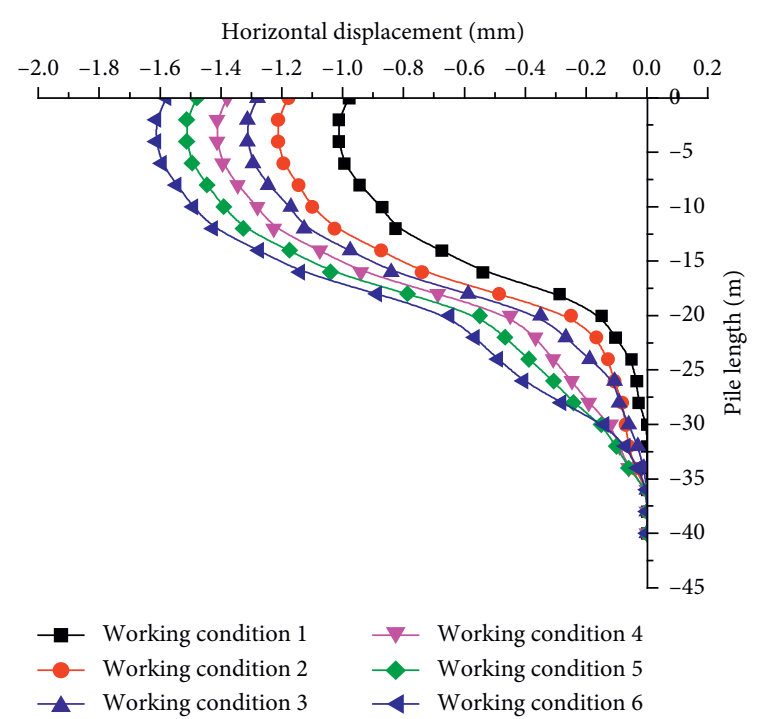

(a)

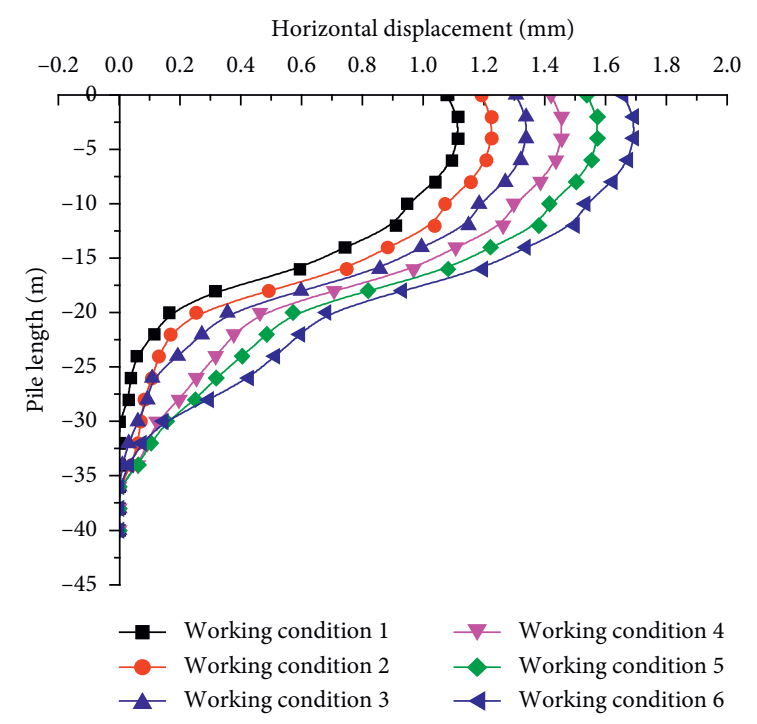

(b)

Figure 21: Horizontal displacement curve of pile foundation under different working conditions. (a) Measuring point 27. (b) Measuring point 29.

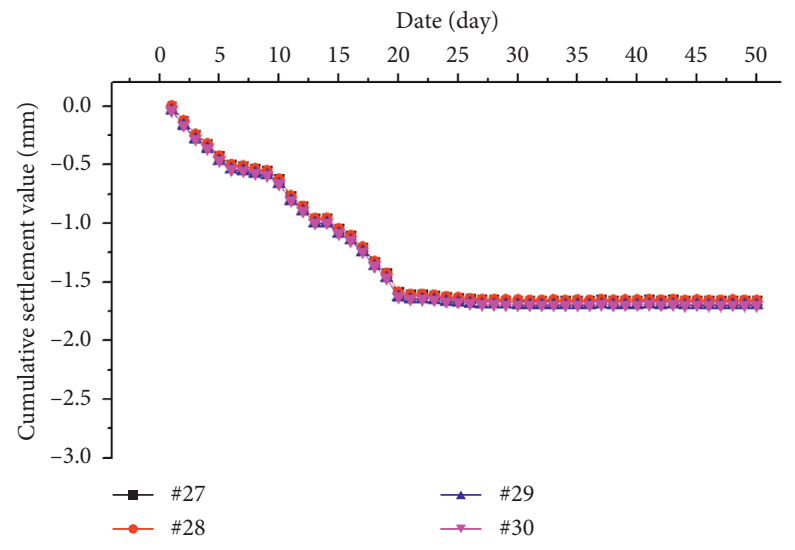

Figure 22: Vertical settlement duration curve of pile foundation.

TABLe 2: Summary table of vertical accumulated settlement at key locations.

\begin{tabular}{lccc}
\hline Serial number & Monitoring point number & Cumulative settlement $(\mathrm{mm})$ & Position \\
\hline 1 & $\# 31$ & -0.7 & Sewage pipe \\
2 & $\# 32$ & -0.4 & Rainwater pipe \\
3 & $\# 33$ & -0.7 & High-pressure gas pipe \\
4 & $\# 34$ & -1 & Residential building \\
\hline
\end{tabular}

TABLE 3: Comparison of monitoring results and numerical simulation.

\begin{tabular}{lccc}
\hline Reinforcement measures & Position & Monitoring $(\mathrm{mm})$ & Simulating value $(\mathrm{mm})$ \\
\hline \multirow{3}{*}{ Ungrouted reinforcement } & The ground settlement & 6.89 \\
& Diaphragm wall & & 7.98 \\
& Pile foundation & 6.25 & 2.52 \\
Grouting reinforcement & The ground settlement & 2.47 & 1.42 \\
& Diaphragm wall & 1.51 & 1.63 \\
\hline
\end{tabular}




\section{Conclusions}

This paper studies that the subway station can effectively control the ground settlement by strengthening the strength of the surrounding structure and grouting to reinforce the stratum, so as to ensure that the construction process of the deep foundation settlement is within the controllable range. The following main conclusions are drawn:

(1) The excavation of the foundation pit of the metro station in silt and silty clay will have an effect on the ground settlement within 20 meters. The settlement can reach $9 \mathrm{~mm}$, and the horizontal displacement can reach $7 \mathrm{~mm}$.

(2) In the process of excavation, with the increase of excavation depth, the vertical settlement and horizontal displacement of the stratum and the surrounding buildings are increasing obviously.

(3) The ground settlement can be effectively controlled by grouting, and the vertical settlement can be controlled within $3 \mathrm{~mm}$, and the horizontal displacement can be controlled within $2 \mathrm{~mm}$.

(4) In this paper, the settlement deformation law of the subway station crossing viaduct is studied by numerical simulation and in-situ monitoring. The error between numerical simulation and field monitoring is $5.9 \%$. The data of numerical simulation can be used for reference in similar projects.

\section{Data Availability}

The data used to support the findings of this study are included within this article.

\section{Conflicts of Interest}

The authors declare that they have no conflicts of interest regarding the publication of this paper.

\section{Acknowledgments}

This work was funded by the National Natural Science Foundation of China (51278246), Young Backbone Teachers Training Program for Colleges and Universities of Henan Province (2019GGJS223), Soft Science Research Program of Henan Province (20200106021), and Science and Technology Program of Henan Province (172102310459).

\section{References}

[1] M. R. Darabpour, M. Darabpour, J. Majrouhi Sardroud, J. Smallwood, and G. Tabarsa, "Practical approaches toward sustainable development in Iranian green construction," Civil Engineering Journal, vol. 4, no. 10, pp. 2450-2465, 2018.

[2] B.-G. Hwang, M. Shan, and S. L. Phuah, "Safety in green building construction projects in Singapore: performance, critical issues, and improvement solutions," KSCE Journal of Civil Engineering, vol. 22, no. 2, pp. 447-458, 2018.

[3] B. X. Yuan, M. Sun, Y. Wang et al., "Full 3D displacement measuring system for 3D displacement field of soil around a laterally loaded pile in transparent soil," International Journal of Geomechanics, vol. 19, no. 5, Article ID 04019028, 2019.

[4] Z. Zhou and W. Guo, "Applications of item response theory to measuring the safety response competency of workers in subway construction projects," Safety Science, vol. 127, Article ID 104704, 2020.

[5] Z. Luo, L. Zeng, H. Pan et al., "Research on construction safety risk assessment of new subway station close-attached undercrossing the existing operating station," Mathematical Problems in Engineering, vol. 2019, Article ID 3215219, 2019.

[6] B. Yuan, M. Sun, L. Xiong, Q. Luo, S. P. Pradhan, and H. Li, "Investigation of 3D deformation of transparent soil around a laterally loaded pile based on a hydraulic gradient model test," Journal of Building Engineering, vol. 28, no. 3, Article ID 101024, 2020.

[7] T. Guo, Z. Cao, Z. Zhang, and A. Li, "Numerical simulation of floor vibrations of a metro depot under moving subway trains," Journal of Vibration and Control, vol. 24, no. 18, pp. 4353-4366, 2018.

[8] B. X. Yuan, L. Xiong, L. Zhai et al., "Transparent synthetic soil and its application in modeling of soil-structure interaction using optical system," Frontiers in Earth Science, vol. 7, p. 276, 2019.

[9] S. Zhang, X. Cheng, K. Zhu, Y. Yao, L. Shi, and H. Zhang, "Experimental study on curved flame characteristics under longitudinal ventilation in a subway tunnel," Applied Thermal Engineering, vol. 114, pp. 733-743, 2017.

[10] B. H. Yan, C. Wei, S. J. Liu et al., "Application of bridge lifting technology when subway undercrossing bridge with a short distance," Construction Technology, vol. 23, 2012.

[11] Y. Zhou, D. Meng, and Q. Guo, "Influence of seismic effect of bridge piles on a subway station," Journal of Vibroengineering, vol. 16, no. 5, pp. 2418-2425, 2014.

[12] B. Peng, N. Zhang, and Q. Zhang, "Research of seismic behavior of subway station crossed by bridge based on time history analysis method," in ICRT 2017: Railway Development, Operations, and Maintenance, pp. 28-35, American Society of Civil Engineers, Reston, VA, USA, 2018.

[13] J. Su, Q. Fang, D. Zhang et al., "Bridge responses induced by adjacent subway station construction using shallow tunneling method," Advances in Civil Engineering, vol. 2018, Article ID 8918749, 2018.

[14] Y. Chen, C. Wang, J. B. Hui Yap, H. Li, and S. Zhang, "Emergency evacuation simulation at starting connection of cross-sea bridge: case study on haicang avenue subway station in xiamen rail transit line," Journal of Building Engineering, vol. 29, Article ID 101163, 2020.

[15] T. Kishii, "Use and area management of railway under-viaduct spaces and underground spaces near stations," Japan Railway \& Transport Review, no. 69, pp. 6-15, 2017.

[16] Z. Wang, X. Guo, and C. Wang, "Field monitoring analysis of construction process of deep foundation pit at subway station," Geotechnical and Geological Engineering, vol. 37, no. 2, pp. 549-559, 2019.

[17] Z. Li, Z. Chen, L. Wang, Z. Zeng, and D. Gu, "Numerical simulation and analysis of the pile underpinning technology used in shield tunnel crossings on bridge pile foundations," Underground Space, vol. 5, no. 6, pp. 1-13, 2020.

[18] W. Pan, Z. Gao, C. Zheng, and Z. Gong, "Analysis on the influence of cross tunnel construction on the deformation of the existing high-speed railway tunnel," Geotechnical and Geological Engineering, vol. 36, no. 6, pp. 4001-4013, 2018.

[19] X. Liu, Y. Liu, Z. Yang, and C. He, "Numerical analysis on the mechanical performance of supporting structures and ground 
settlement characteristics in construction process of subway station built by Pile-Beam-Arch method," KSCE Journal of Civil Engineering, vol. 21, no. 5, pp. 1690-1705, 2017.

[20] F. Lv, F. Ren, and L. L. Zhang, "Study on deformation influence of shield tunnel passing through existing railway bridge piles," IOP Conference Series: Earth and Environmental Science, vol. 189, no. 2, Article ID 022088, 2018.

[21] J. Zhao, W. Meng, and F. Sun, "Construction risk assessment of metro elevated station based on C-OWA operator and improved extenics," IOP Conference Series: Earth and Environmental Science, vol. 525, no. 1, Article ID 012012, 2020.

[22] Z. Yang and X. Wang, "Influence of metro tunnel excavation on deformation of existing pedestrian underpass in changzhou railway station platform," IEEE Access, vol. 8, pp. 55860-55871, 2020.

[23] P. Jia, W. Zhao, X. Du et al., "Study on ground settlement and structural deformation for large span subway station using a new pre-supporting system," Royal Society Open Science, vol. 6, no. 2, Article ID 181035, 2019.

[24] L. L. Zhang, "Study on underpinning scheme of viaduct pile foundation crossed by shield tunnel," IOP Conference Series: Earth and Environmental Science, vol. 570, no. 5, Article ID 052028, 2020.

[25] C. K. Wang, "Analysis on influence of minor radius shortdistance shield tunnel side crossing viaduct pile foundation," Urban Roads Bridges \& Flood Control, vol. 97, no. 6, 2017.

[26] X. Y. Tian and S. C. Gu, "Influences of subway tunnel on the adjacent existing bridge piles and optimization of construction methods," Urban Mass Transit, vol. 33, no. 3, 2017.

[27] B. Wu, Z. J. Zhang, and W. Huang, "Comparison and selection of reinforcement schemes for shield tunnelling close crossing high-speed railway viaduct group," IOP Conference Series: Earth and Environmental Science, vol. 267, no. 4, Article ID 042119, 2019.

[28] D. Y. Wang, K. Wu, J. Wang et al., "Deformation monitoring and simulation analysis of deep foundation excavation construction for subway station," IOP Conference Series: Earth and Environmental Science, vol. 580, no. 1, Article ID 012027 , 2020.

[29] M. Zhang and J. P. Liu, "Safety influence on subway station adjacent to foundation pit and enclosure structure by excavation construction," Electronic Journal of Geotechnical Engineering, vol. 22, no. 14, pp. 5387-5397, 2017.

[30] B. Li, W. Sun, and G. K. Li, "Analysis of influence of subway station deep foundation pit excavation on adjacent bridge piles," IOP Conference Series: Materials Science and Engineering, vol. 789, no. 1, Article ID 012033, 2020. 